\title{
VISUAL IMPACT ASSESSMENT OF WIND TURBINES ON LANDSCAPE IN S̆ILALE் REGION
}

\author{
Jonas ABROMAS, Department of Landscape Architecture and Environmental Design, Klaipėda University, K. Donelaičio g. 4, \\ LT-92144, Klaipèda, Lithuania, jonasabromas@yahoo.com (corresponding author) \\ Petras GRECEVIČIUS, Department of Landscape Architecture and Environmental Design. Architecture, Urban Planning and Design \\ Center „Baltic landscapes“, Klaipèda University, K. Donelaičio g. 4, LT-92144, Klaipèda, Lithuania, petras.grecevicius@ ku.lt \\ Nijolė PIEKIENÉ, Vilnius Gediminas Technical University, Department of Landscape Architecture and Environmental Design, \\ Klaipèda University, K. Donelaičio g. 4, LT-92144, Klaipėda, Lithuania, nijole.lin@ gmail.com
}

\begin{abstract}
Due to their visual - spatial parameters, these sites are becoming dominant verticals thus changing the local landscape and its visual quality, which in turn determines the quality of the living environment. In order to preserve the identity of the regional landscape, it is important to estimate the potential impact of both existing and planned wind turbines on the landscape.

Visual impact of wind turbines depends on a number of features: the size, color and shape of the turbine, observation distance, landscape diversity, time of day, and many other factors.

Visual impact of wind farms located in the region of Šilale is analyzed in the paper. The main aim of the paper is after comparison of theoretical sizes of visual influence zones and degrees of visual significance with the results of empirical research, to establish possible ways of elaboration of methodology of visual impact assessment establishing visual influence zones. The main results of the research are established major factors of visual impact of wind farms, sizes of zones of visual influence and character of visual impact in different zones of visual influence.
\end{abstract}

Keywords: wind turbines, environmental impact assessment, the influence of wind turbines on environment.

\section{INTRODUCTION}

Wind turbines are becoming an integral part of the landscape in Western Lithuania. The hub height of the wind turbines currently under construction reaches $80-120 \mathrm{~m}$, while the blade-tip height is $120-150 \mathrm{~m}$. Under good visibility conditions, wind turbines can be visible from up to $25-30 \mathrm{~km}$ distance. Their construction in the area is initiated by the average annual wind speed, reaching 6-7 m/s. Although this region has important protected areas, resorts, intensive tourist routes. Also, quite often problems arise when wind turbines are built in the area of natural framework, in the approaches to the national and regional parks, near the important site of cultural heritage and their visual protection zones, and villages. Due to these aspects, the valuable landscape has changed in some areas, since the future impact of the wind turbines under construction had not been adequately estimated.

Visual impact of wind turbines depends on a number of features: the size, color and shape of the turbine, observation distance, landscape diversity, time of day, and many other factors. Visibility itself usually includes even several types of landscapes. Therefore, in order to properly assess the visual impact, the size of the landscape area to be visually impacted should be determined, i.e. it is important to determine the extent of the visual impact zone of a wind turbine. As a result, determining the visual impact zone of a wind turbine as a visual dominant of the landscape, and estimating the nature of the impact becomes especially relevant.

Visual impact of wind farms located in the region of Šilale is analyzed in the paper. The main aim of the paper is after comparison of theoretical sizes of visual influence zones and degrees of visual significance with the results of empirical research, to establish possible ways of elaboration of methodology of visual impact assessment establishing visual influence zones. The main results of the research are established major factors of visual impact of wind farms, sizes of zones of visual influence and character of visual impact in different zones of visual influence.

\section{RESULTS OF RESEARCH}

In seeking to assess the impact of the wind turbines located in Šilalè region on the landscape and villages, all cartography material was analyzed and the inventory of all wind turbines was made (GIS data of turbines location was

Copyright (C) 2015 The Authors. Published by Aleksandras Stulginskis University. This is an open-access article distributed under the terms of the Creative Commons Attribution License (CC-BY 4.0), which permits unrestricted use, distribution, and reproduction in any medium, provided the original author and source are credited. 
worked out). On assessing the importance of the roads in situ, the importance of the impact of the wind turbines was grouped in terms of degrees (Fig. 1):

- Visually dominating (about $0-1 \mathrm{~km}$ ). Wind turbines dominate in the observation area due to their bulky size. Essentially change the sight of the neighbouring environment. The movement of the rotor is clear;

- Generally dominating (about 1-3 km.). The turbines look bulky and are a significant element of the landscape; however, they do not necessarily dominate in the observation area. The movement of the blade is clearly perceived and attracts attention;

- $\quad$ Noticeable (accents) (about 3-7 km). Wind turbines are clearly visible, but they aren't visually unwanted any more. The wind farm is noticeable as an element of landscape. The movement is noticeable at good visibility. The turbines do not look large in the overall field of view. Some changes in the landscape due to the emergence of the turbines are acceptable. The observation is influenced by weather conditions;

- Subdominants (about 7-10 km). Wind turbines are less clearly visible, the size is visually diminished, but the movement is noticeable. With the increasing distance, wind turbines become general elements of the landscape;

- Remote elements of the landscape (background elements) (>10 km). The turbines are no longer clear, of a small shape and look insignificant. The movement of the blades is generally unnoticeable. The overall size of the turbines is very small (authors of the article, and Jallouli, Moreau 2009).


Figure 1. Diagrams of the significance of the impact of the wind turbines in terms of degrees: 1 - visually dominating, 2 - generally dominating, 3 - accents, 4 - subdominants, 5 - background elements (author of the schemes: J. Abromas, 2015)

Calculating the size of viewing angles. Taking into account the parameters of the vertical field of human vision, it is important to determine the size of wind turbine's viewing angle when observing from the particular observation deck chosen (see Figure 2-4).

When the vertical viewing angle of wind turbine is up to $0.5^{\circ}$ - the visual impact is not significant. The referred viewing angle is determined by an observation distance. With shorter observation distance and the vertical viewing angle of $0.5^{\circ}-2.5^{\circ}$ - visually, wind turbines become potentially visible. When observing wind turbines from even smaller distance, and with the viewing angle of $2.5^{\circ}-5^{\circ}$ - wind turbines become visually dominant.

It is particularly important to assess the size of the viewing angle when observing wind turbines from important observation deck in terms of cultural heritage and tourism. In determining the size of the viewing angle, Siements SWT-2.3-101 wind turbines in Šilale district were analyzed. The visible angle was calculated under three different situations: when the wind turbine is fully visible; when the wind turbine's rotor and tower's upper part is visible; when 
only the blades are visible. Parameters of the referred wind turbines: tower height $-99.5 \mathrm{~m}$; rotor diameter $-101 \mathrm{~m}$; blade-tip height $-150 \mathrm{~m}$; and blade length $-50.5 \mathrm{~m}$. In all cases, the wind turbine was observed from a $1000 \mathrm{~m}$ distance.

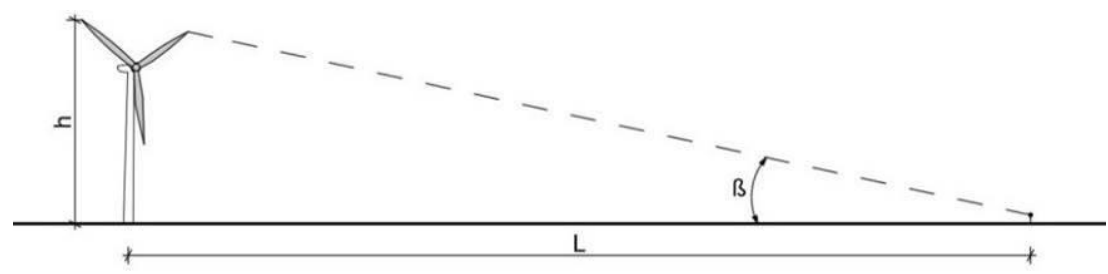

Figure 2. Observation angle of openly visible wind turbine, and its calculation (author of the scheme: J. Abromas, 2015)

$\mathrm{h}$ - Height of wind turbine $(150 \mathrm{~m})$

$\mathrm{L}$ - Distance between the observer and wind turbine $(1000 \mathrm{~m})$

$\beta$ - Observation angle of wind turbine

Calculation of the angle $\beta$ of an openly visible wind turbine:

$B=\arctan \frac{h}{L}=\arctan \frac{150}{1000}=8,53^{\circ}$

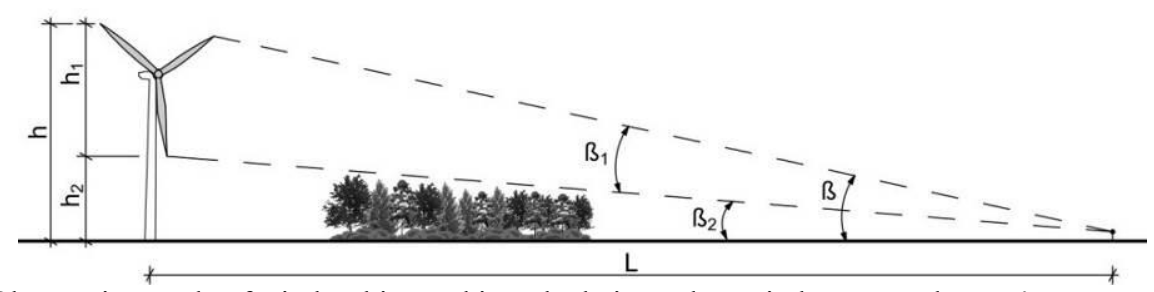

Figure 3. Observation angle of wind turbine and its calculation, when wind motor and tower's upper part is visible (author of the scheme: J. Abromas, 2015)

$\mathrm{h}-$ Height of wind turbine $(150 \mathrm{~m})$

$\mathrm{h}_{1}-$ Rotor diameter $(101 \mathrm{~m})$

$\mathrm{h}_{2}$ - Tower height up to the blade's lowest point

$\mathrm{h}_{2}=\mathrm{h}-\mathrm{h}_{1}=150-101=49 \mathrm{~m}$

$\mathrm{L}$ - Distance between the observer and wind turbine $(1000 \mathrm{~m})$

$\beta / \beta_{1} / \beta_{2}-$ Observation angles of wind turbine

$\beta=8,53^{\circ}$ (see calculation in Fig. 2)

Calculation of the angle $\beta_{1}$ when the rotor and the tower's upper part is visible

$\mathbb{B}_{2}=\arctan \frac{h_{2}}{L}=\arctan \frac{49}{1000}=2,81^{\circ}$

$\beta_{1}=\beta-\beta_{2}=8.53^{0}-2.81^{0}=5.72^{0}$

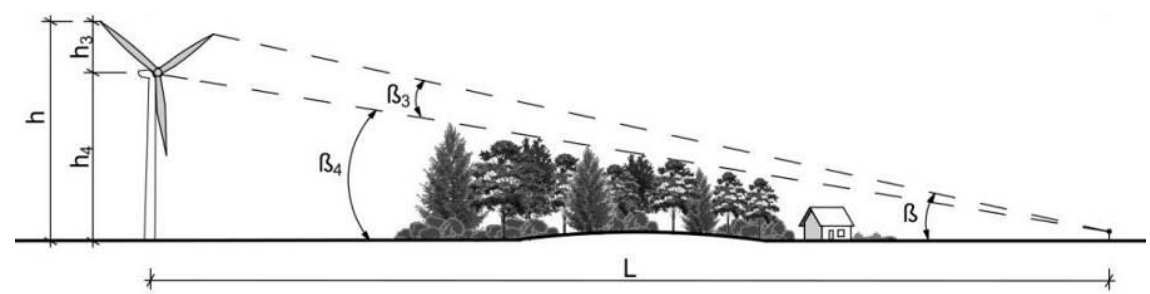

Figure 4. Observation angle of wind turbine and its calculation, when only wind turbine blades are visible (author of the scheme: J. Abromas, 2015)

$\mathrm{h}$ - Height of wind turbine $(150 \mathrm{~m})$

$\mathrm{h}_{3}$ - Blade length $(50.5 \mathrm{~m})$

$\mathrm{h}_{4}-$ Tower's height $(90.5 \mathrm{~m})$

$\mathrm{L}$ - Distance between the observer and wind turbine $(1000 \mathrm{~m})$

$B / \beta_{3} / \beta_{4}-$ Observation angles of wind turbine

$\beta=8,53^{\circ}$ (see calculation in Fig. 3)

Calculation of the angle $\beta_{3}$ when only the blades are visible 


$$
\begin{aligned}
& \mathrm{B}_{4}=\arctan \frac{h_{4}}{L}=\arctan \frac{99,5}{1000}=5,68^{\circ} \\
& \beta_{3}=\beta-\beta_{4}=8,53^{\circ}-5,68^{\circ}=2,85^{\circ}
\end{aligned}
$$

The wind farm in Šilale region was constructed in 2012. There are 6 wind turbines (type of which is Siemens SWT-2.3-101). The height of their towers is $99,5 \mathrm{~m}$, the total diameter of the set of blades is $101 \mathrm{~m}$, and the total height of wind turbine with one of the blades at the top position is $150 \mathrm{~m}$. Capacity of one wind turbine is $2,3 \mathrm{MW}$. This is the first wind farm built not in the littoral zone. The distance from the Baltic Sea is $60 \mathrm{~km}$. This wind farm is near highway A1 Vilnius - Klaipeda. Considering this the observation points are located on this highway (Fig. 5).

On the territory of the wind farms landscape with middle vertical dispersion exists (hilly and sloppy landscape with complexes of three-level videotops). Half-open agricultural visual spaces of moraine hills prevail.

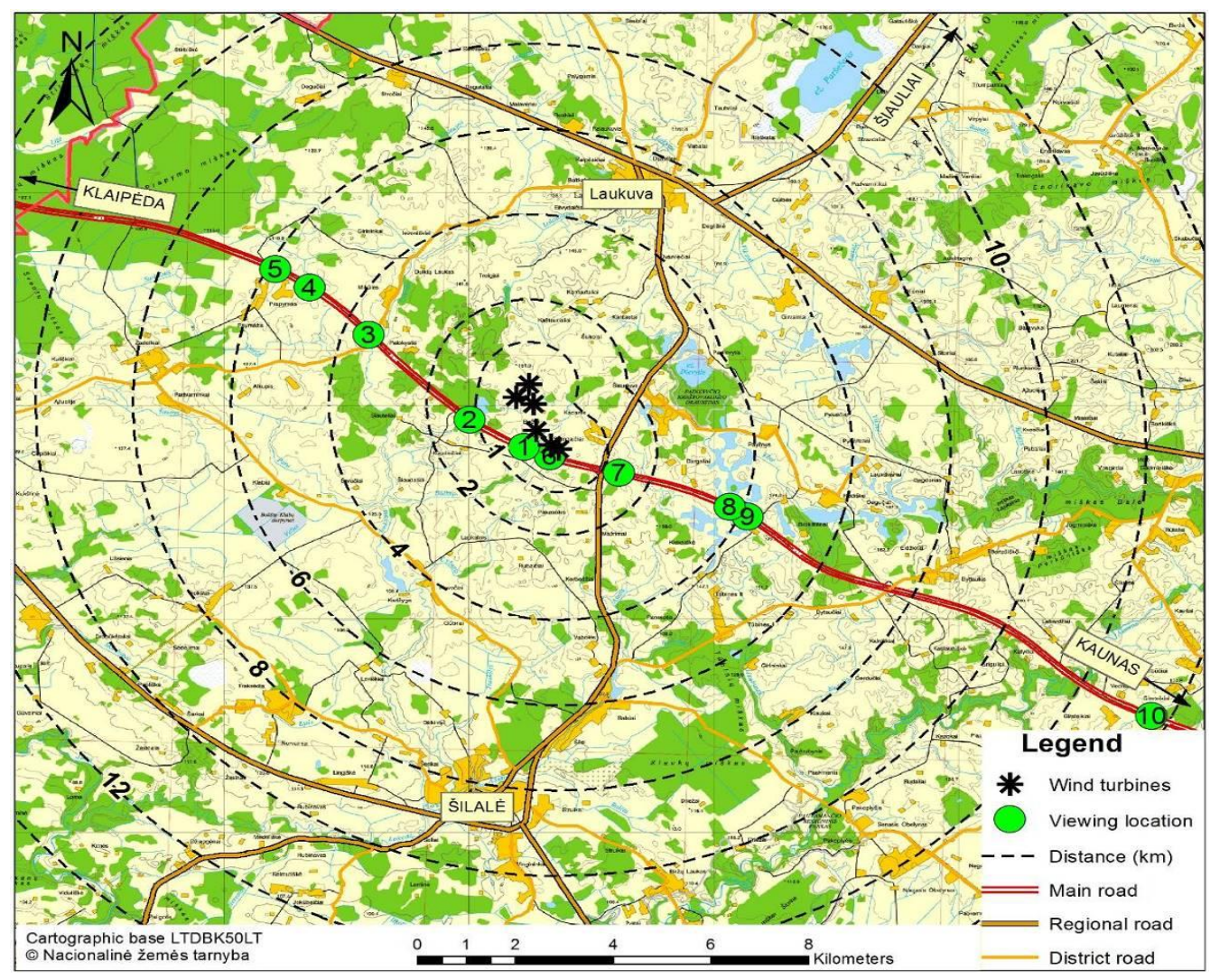

Figure 5. Locations of wind turbines and viewing points (author of the map: J. Abromas, 2015)

Table 1. Assessment of the significance of visual impact of wind turbines and the degree of contrast as well as the nature of the

\begin{tabular}{|c|c|c|}
\hline $\begin{array}{l}\text { The number and } \\
\text { direction of } \\
\text { observation point } \\
\text { on the highway }\end{array}$ & $\begin{array}{l}\text { Distance to } \\
\text { wind turbines } \\
\quad(\mathrm{km})\end{array}$ & Visual impact degree \\
\hline $\begin{array}{l}\text { 1. The point closest } \\
\text { to the wind farm }\end{array}$ & 0,5 & $\begin{array}{l}\text { As wind turbines are constructed in the higher elevation sites their dominance in } \\
\text { landscape increases. The existing vegetation only partially screens the lower parts of the } \\
\text { towers. Due to the observation distance and height of the wind turbines }(150 \mathrm{~m}) \text { they } \\
\text { dominate in the visual space. }\end{array}$ \\
\hline $\begin{array}{l}\text { 2. Going in the } \\
\text { direction of Vilnius }\end{array}$ & 1,5 & $\begin{array}{l}\text { Due to the nearby wood, half/two thirds of the lower part of turbines towers cannot be } \\
\text { seen, and the dominance of the turbines decreases. }\end{array}$ \\
\hline $\begin{array}{l}\text { 3. Going in the } \\
\text { direction of Vilnius }\end{array}$ & 4 & $\begin{array}{l}\text { Due to the dense wood only the set of blades of the wind turbines are seen. The } \\
\text { movement of blades is seen clearly. The wind turbines become landscape accents. }\end{array}$ \\
\hline $\begin{array}{l}\text { 4. Going in the } \\
\text { direction of Vilnius }\end{array}$ & 5,5 & $\begin{array}{l}\text { Due to the nearby wood and observation point situated in the higher elevation site, one } \\
\text { third of the lower part of turbines towers cannot be seen but wind turbines dominate in } \\
\text { the landscape. }\end{array}$ \\
\hline $\begin{array}{l}\text { 5. Going in the } \\
\text { direction of Vilnius }\end{array}$ & 6 & $\begin{array}{l}\text { The wind turbines are seen from the road Klaipeda - Vilnius from this observation point. } \\
\text { Due to the hilly terrain and woods only the set of blades of one wind turbine and parts of } \\
\text { blades of the rest turbines are seen. }\end{array}$ \\
\hline $\begin{array}{l}\text { 6. Going in the } \\
\text { direction of } \\
\text { Klaipeda }\end{array}$ & 2 & $\begin{array}{l}\text { The roadbed screens the towers of wind turbines. Only the lower part of the tower of the } \\
\text { closest turbine is screened and only sets of blades of the further ones are seen. Despite } \\
\text { these aspects the wind turbines dominate in landscape. }\end{array}$ \\
\hline
\end{tabular}
impact from the observation places 


\begin{tabular}{|l|c|l|}
\hline $\begin{array}{c}\text { The number and } \\
\text { direction of } \\
\text { observation point } \\
\text { on the highway }\end{array}$ & $\begin{array}{c}\text { Distance to } \\
\text { wind turbines } \\
(\mathbf{k m})\end{array}$ & \multicolumn{1}{|c|}{ Visual impact degree } \\
\hline $\begin{array}{l}\text { 7. Going in the } \\
\text { direction of } \\
\text { Klaipeda }\end{array}$ & 4,5 & $\begin{array}{l}\text { Different location of the observed turbines, vegetation, hills, bend of the highway, } \\
\text { moving cars don't let to dominate all the turbines. The wind turbine on the hill } \\
\text { dominates and the rest of them become landscape accents (fig. 1). }\end{array}$ \\
\hline $\begin{array}{l}\text { 8. Going in the } \\
\text { direction of } \\
\text { Klaipeda }\end{array}$ & 5 & $\begin{array}{l}\text { The towers of wind farms are screened by woods and advertising stands. The wind } \\
\text { turbines become landscape accents. }\end{array}$ \\
\hline $\begin{array}{l}\text { 9. Going in the } \\
\text { direction of } \\
\text { Klaipeda }\end{array}$ & 14 & $\begin{array}{l}\text { The movement of blades is seen but the wind turbines are not visually clear. They } \\
\text { become background elements. }\end{array}$ \\
\hline
\end{tabular}

After accomplishing field survey and structuring the data, the zones of visual influence were revised. There are recommended such intervals of zones of visual influence: $0-1 \mathrm{~km} ; 1-3 \mathrm{~km} ; 3-5 \mathrm{~km} ; 5-7 \mathrm{~km} ; 7-10 \mathrm{~km} ; 10-13 \mathrm{~km}$; 13-16 km; 16-20 km; >20 km. At a distance of $0-3 \mathrm{~km}$ wind turbines usually dominate in landscape, at a distance of 4-7 km - they become accents, at a distance of 8-10 km - subdominants and at a distance of $>10 \mathrm{~km}-$ background elements.

Wood near the observation point has a big influence on the visual impact of the wind farm. Atmospheric conditions such as cloudiness also have a big influence on the visual impact of the wind farm. The color of the wind turbines is white. When clouds are of the same or similar color the set of blades in some cases can be invisible or on the contrary can be visible more clearly if the clouds are darker.

The more anthropogenic objects are in the visual space the more visual impact of the wind farm is decreased. In some cases wind farm can become a background element.

Evaluating visual impact of wind turbines in Šilale region visibility of the turbines was conditioned by the additional factor - terrain undulations. Due to this aspect (as well as forested areas) going by highway in the direction of Vilnius the wind turbines become visible only at $6 \mathrm{~km}$ distance (Table 1).
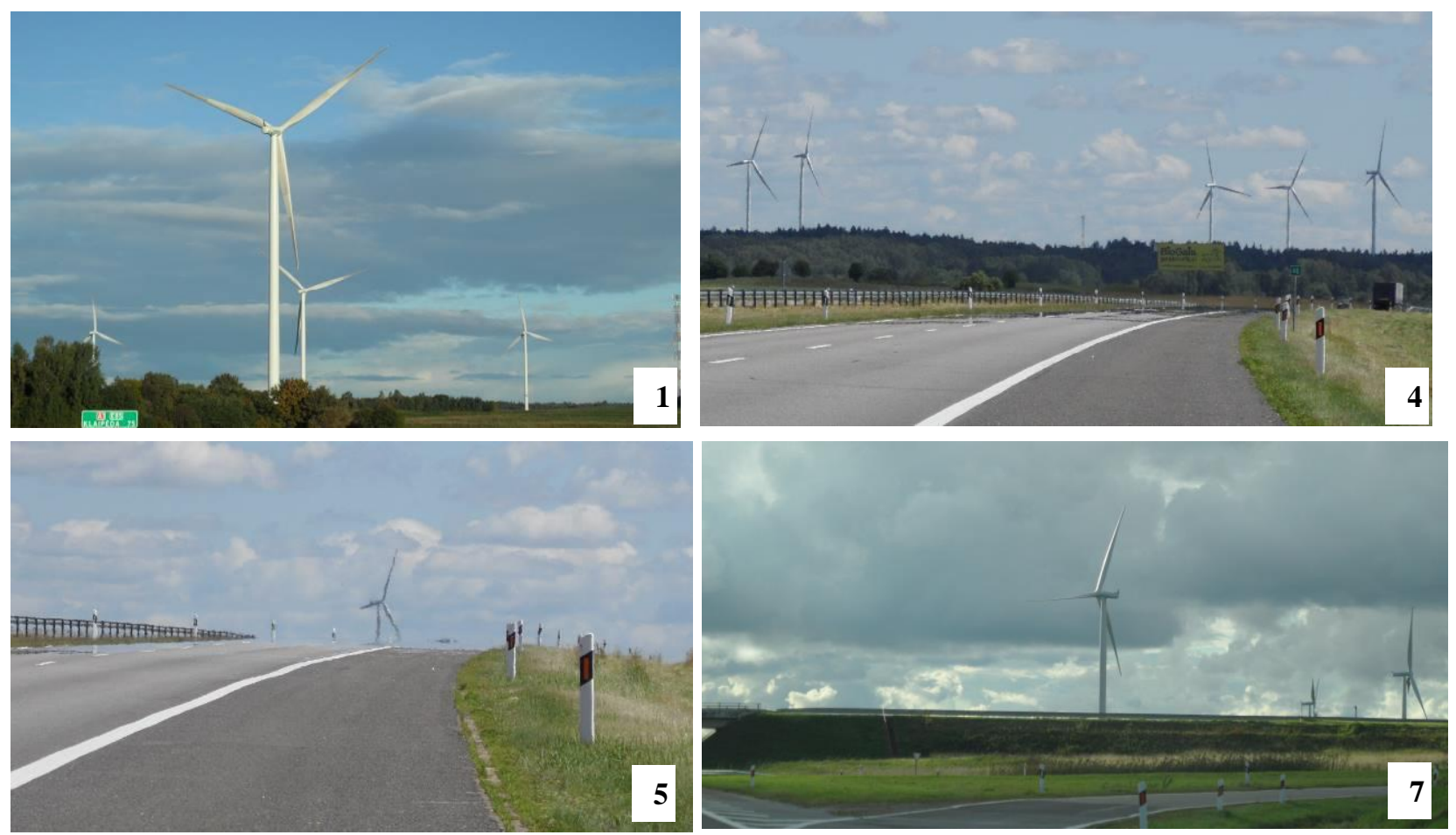

Figure. 6. Photos made from observation points No.: 1, 4, 5, 7 (photos by J. Abromas, 2013)

\section{CONCLUSIONS}

Evaluating visual impact of wind turbines in Šilale region visibility of the turbines was conditioned by the additional factor - terrain undulations. Due to this aspect (as well as forested areas) going by highway in the direction of Vilnius the wind turbines become visible only at $6 \mathrm{~km}$ distance.

The more anthropogenic objects are in the visual space the more visual impact of the wind farm is decreased. In some cases wind farm can become a background element.

The analysis of the target location has to be carried out in order to select a proper location for wind turbines: landscape characteristics (Recommendations for the assessment of the environmental impact of the planned economic 
activities (wind turbines). The visual impact of wind turbines on cultural heritage objects is analyzed on the level of the predominant type of landscape, naturalness, mosaicking, diversity, tradition, regional value, and on the aspects of aesthetic features, main observation decks, observation points and panoramas, as well as visiting places. Wind turbine layout and territory boundaries are formed away from the preserved areas, like Varniai and Pagramantis regional parks, landscape reserves, hydrographic reserves, and the protected wetland complex. However, Šilale district mounds, i.e. Rubaičai (called Pilalè), Padievytis and Treigiai, located about 2-3 km away from the wind farm, are enlisted in the List of Cultural Heritage Objects of Šilale District. In the analyzed case, there is a potential impairment of the impact of wind turbines on the visibility of the traditional landscape with its preserved natural and cultural values.

Even though the blade-tip height of the major wind turbines (up to 120-150 m) are observed at the distance of $30 \mathrm{~km}$ at good visibility, the visual effect on the landscape is produced only by background elements located at the distance of $15-20 \mathrm{~km}$. When viewed from the roads and from a dynamic position, a more significant effect is produced by the wind turbines located nearer the roads. The turbines located farther from the observer (at a distance of 10-20 km) make visual influence only when seen on the road perspective axis.

\section{REFERENCES}

1. Bučas, J. 2001. Karštotvarkos pagrindai. Kaunas: Technology, p. 282.

2. Bureau of Land Management. 2012. Visual Resource Contrast Rating: Information Document. Washington.

3. Cialdea, D., Maccarone, A., Sollazzo, A. 2010. Wind energy and landscape in Molise - Legislation, Incentives and Problems, International Conference on Renewable Energies and Power Quality (ICREPQ'10.) Granada (Spain).

4. Domingo-Santos, J. M., Fernández de Villarán, R. F., Rapp-Arrarás, Í., Corral-Pazos de Provens, E. 2011. The visual exposure in forest and rural landscapes: An algorithm and a GIS tool. Landscape and Urban Planning, Vol. 101, pp. 52-58. http://dx.doi.org/10.1016/j.landurbplan.2010.11.018

5. Enviromental Resources Management. 2009. Ararat Wind Farm Victoria. Landscape and visual assessment report. Australia. Available at http://www.res-australia.com/media/413609/02\%20-\%20Landscape\%20\&\%20Visual\%20Assessment.pdf

6. Frantál, B., Kunc, J. 2011. Wind turbines in tourism landscapes: Czech Experience. Annals of Tourism Research, Vol. 38, Iss.2, pp. 499-519. http://dx.doi.org/10.1016/j.annals.2010.10.007

7. Homewood, A. 2011. Eden Wind Farm. Landscape and visual impact assessment. Australia.

8. Jallouli, J., Moreau, G. 2009. An immersive path-based study of wind turbine landscape: A French case in Plouguin. Denmark. Renewable Energy, Vol. 34, pp. 597-607. http://dx.doi.org/10.1016/j.renene.2008.05.036

9. Kamičaitytė-Virbašienè, J. 2001. Landscape visual quality, the importance and problems of its regulation. Town Planing and Architecture, Vol. 4, pp. 202-209.

10. Kamicaityte-Virbašienè, J., Abromas, J. 2012. Problems of Determining Size and Character of Wind Turbines' Visual Impact Zones on Lithuanian Landscape. Environmental Research, Engineering and Management, Vol. 4, Iss. 62, pp. 21-29.

11. Katsaprakakis, D. A. 2012. A review of the environmental and human impacts from wind parks. A case study for the Prefecture of Lasithi, Crete. Renewable and Sustainable Energy Reviews, Vol. 16, pp. $2850-2863$. http://dx.doi.org/10.1016/j.rser.2012.02.041

12. Kavaliauskas, P. 2006. The identification study of the diversity of spatial structure and its types in the landscape of the Republic of Lithuania. Vilnius. Available at http://www.am.lt/VI/index.php\#r/1144

13. LITGRID. 2013. Report on the electric power generated from renewable resources. Available at http://www.litgrid.eu/go.php/lit/Ataskaitos/202

14. Möller, B. 2006. Changing wind-power landscapes: regional assessment of visual impact on land use and population in Northern Jutland, Denmark. Applied Energy, Vol. 83, pp. 477-494. http://dx.doi.org/10.1016/j.apenergy.2005.04.004

15. Pakalnis, R., Venckus, Z. 2012. Landscape ecology. Šiauliai. Preliminary Landscape and Visual Impact Assessment Report. Dundonnell Wind Farm. Prepared on behalf of NewWn Australia Pty Ltd. 2012.

16. The European Wind Energy Association. 2012. Wind in power. 2012 European statistics. Available at http://www.ewea.org/fileadmin/files/library/publications/statistics/Wind_in_power_annual_statistics_2012.pdf

17. Tsoutsos, T., Tsouchlaraki, A., Tsiropoulos, M., Serpetsidakis, M. 2009. Visual impact evaluation of a wind park in a Greek island. Denmark. Applied Energy, Vol. 86, pp. 546-553. http://dx.doi.org/10.1016/j.apenergy.2008.08.013

18. University of Newcastle. 2002. Visual Assessment of Windfarms: Best Practice. Scottish Natural Heritage Commisioned Report F01AA303A. 